\title{
NeW MeThods OF ONLINE AdVERTiSing: SOCIAL MEDIA INFLUENCERS
}

\author{
Dominik Zeljko, Bozidar Jakovic \& Ivan Strugar
}
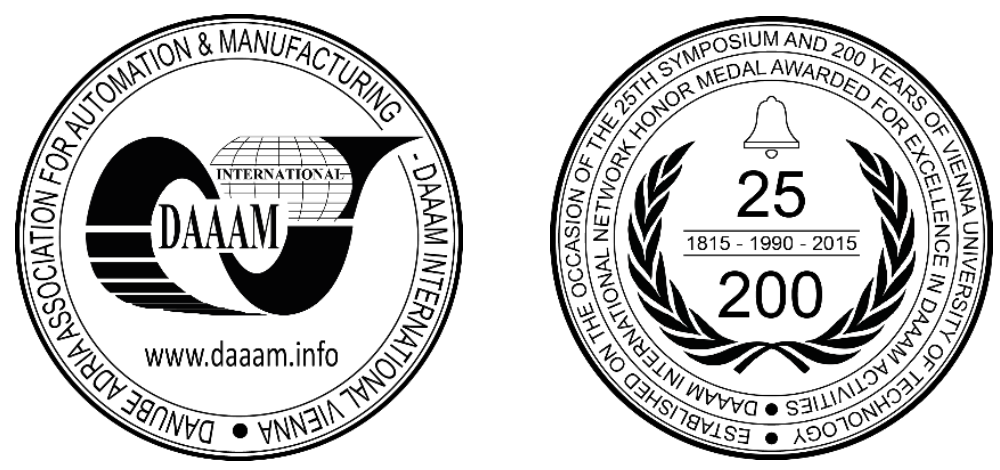

This Publication has to be referred as: Zeljko, D[ominik]; Jakovic, B[ozidar] \& Strugar, I[van] (2018). New Methods of Online Advertising: Social Media Influencers, Proceedings of the 29th DAAAM International Symposium, pp.00410050, B. Katalinic (Ed.), Published by DAAAM International, ISBN 978-3-902734-20-4, ISSN 1726-9679, Vienna, Austria

DOI: $10.2507 / 29$ th.daaam.proceedings.006

\begin{abstract}
Through this paper, a theoretical and empirical part of the field of electronic business is involved in the creation of a platform that will connect companies and influencers. The aim of this paper was to approximate the concept of advertising through social media, their advantages and issues in the theoretical part and present the idea of implementing new services on the market through the practical part. The conducted market research fully supports a hypothesis of this paper, emphasizing the use of the proposed e-business model for creating a platform that will connect businesses and influencers as useful and applicable. Based on the results of the research and confirmed needs for the use of the said system, an example of an electronic business model was made.
\end{abstract}

Keywords: electronic business; platform; advertising; social media; influencers

\section{Introduction to Social Networks}

Until beginning of social networks development, which is marked by appearance of first web location for social connecting SixDegrees.com [1], the general concept of web search was limited to one-way web browsing on web pages. The only possibility of two-way communication with owners of those web pages was through forums. Before detailed analysis of social networks, it is necessary to explain the term of social networks, unrelated to current most popular networks. A social network is a web page on which users can create their own profile, edit it, communicate with other users/profiles, share content and advertise if some product or service is being sold [2]. For better understanding of social networks, definition of social networking helps - exchange of information between individuals, groups or institutions [3].

Term of social networks is used to describe social structure which is determined by social interactions. Connections in this structure are called edges, while main social units are called nodes [4]. Nodes that connect any social unit represent convergence of different contacts of specific social unit. Few types of these connections form network between nodes, and that is how social networks are made [5]. Various codes are used to simplify social interactions through social networks. Supplier of service can generate code on users request and forward it to the user with request and other users [6]. To understand social interactions, it is important to investigate this phenomenon through settings of connections that are present inter and intra units, rather than investigating settings of units themselves. 
There is criticism of social network theory and it emphasizes the individual's capacity to act independently and to be responsible for their own doings [7]. The foundation of social media is social media that includes web-based and mobile technologies that are used to turn communication into interactive dialogue. Social media are defined as a group of Internet applications built on the ideological and technological basis of Web 2.0 technology [8][9]. That technology gives additional popularity to social networks because it puts users at the heart of events by enabling them to create content and offer it to other users [10].

Almost all user-generated content sites provide some means to connect and communicate with each other [11]. Individuals are allowed to make a public profile and within a limited system, articulate a list of other users with whom they share their relationship, and see and compare their contact list with those made by other users within the system [12]. Social networks and social networking are not new concepts, in different forms there have always existed. Social networking is a simple act of maintaining or strengthening an existing circle of friends and spreading their circle. In this way it introduces a new network of friends through the already existing ones, which promotes the formation of an individual network and the creation of communities [13].

Social media (networks) are media for social interaction and represent overcoming the very sphere of social communication. Social media that is readily available has changed the way organizations and individuals communicate [14]. Social media include Internet forums, blogs, social blogs, wikis, podcasts, photos and videos. There are six types of social media, including collaborative projects such as Wikipedia. Blogs and microblogs, for example, are Tumblr and Twitter. Furthermore, society content such as YouTube. Social networking sites examples are Facebook and Google Plus. Furthermore, virtual worlds and virtual social worlds. Technologies that are being used include blogs, sharing pictures, video blogs, sending to the wall, email, sending real-time messages, music sharing, Internet telephony and many more. Many of these technologies that are classified as social media technologies can be integrated into a social networking platform [15][16].

Kietzmann introduced a methodology [17] that defines how social media services focus on some or all of the seven constituent parts (identity, conversation, sharing, presence, relationships, reputation, and groups). These blocks help you understand what level of involvement is needed for the audience of social media. For example, LinkedIn users are concerned about identity, reputation, and relationships, while YouTube users are concerned about sharing, conversations, groups and reputation [18]. Many companies build their own social networks to connect all seven blocks around their brands. These are private social networks that involve people with a special brand or hobby. Businesses can consider social media as user-generated content. People get information, education, news and other information from electronic and print media.

Social media differs from traditional media, such as newspapers, television and film. The main difference between social and traditional media is that information in social media is inexpensive and accessible for anyone to publish, while in traditional media, they mostly need significant resources to broadcast some information. One characteristic is shared by social and traditional media, which is the ability to reach a small or large audience. For example, blog publishing and TV shows may be accompanied by a small or very large number of viewers [19].

The purpose of this paper is to investigate new methods of advertising with main focus on social media influencers. The main research question is will it be useful to create a platform that will connect businesses and influencers.

\section{Advertising on Social Networks}

Social media (networks) allow the exchange of ideas, content, thoughts and interpersonal relationships over the Internet. Social media differs from traditional media in that anyone can make content on them. Social media include text, sound, video, image and community of people. Social networks eliminate the need for intermediaries, the traditional media in communication with the groups of potential customers. Social networking is direct and targeted to key segments. Today, therefore, we have a situation in which the traditional techniques used by marketing and public relations for about sixty years are no longer valid [20]. Also, the impact of an individual is significant in comparison to traditional media that have one-way communication. For example, thanks to social media, individuals like certain bloggers and similar public opinion leaders have a stronger influence and credibility than traditional media such as the Wall Street Journal. Since social networks have become ubiquitous, they have also found their place in business, or exploitation of human resources [21]. Business social networks also help employees collaborate with their colleagues in ways that are based on the ideas and experience of all other employees who can now collaborate on innovative ideas [22]. Today social networks such as Facebook, Twitter, LinkedIn, Google+, YouTube, Blog and many others are used as hubs for people who meet and share ideas, but also to promote their work and their own products [23]. It can be said that social networks have changed the way business and advertising function. Companies can improve and maintain their relationship with consumers through social media, inform buyers about certain benefits, promote their brand, or offer some new product or service that will reach large number of users thanks to the social network in a very short time [24].

Social media is divided on blogs, social networks (such as Facebook), forums, wiki sites (Wikipedia), image sharing websites (Flickr) and video sharing websites (YouTube). The basic feature is that they allow each user to be both the recipient and the content provider [25]. Users create content through their activities, and by following other users content determine their popularity. For this reason, the nature of communication that companies can implement through social media is significantly different from other forms of marketing communications on the Internet [26]. 
Considering social media advertising, it can be said that it did not exist 10 years ago, but projections assume $\$ 11$ billion in 2017 sales. Social network ads create brand awareness with targeted promotion based on geographic, demographic, and behavioral information available within the marketing tools that the network offers advertisers. Due to the social network environment and advanced promotional material targeting capabilities, ads are displayed in contexts tailored to each individual user, making them more efficient than the traditional media. According to statistics and estimates, consumption growth in social networking is $80 \%$ in the period from 2013 to 2017 [27].

Social network advertising has been recognized by many as an ideal place for targeting messages and information to potential customers. Enterprises use their social networks to understand consumer behavior, create and manage value for consumers, strengthen their marketplace by informing potential customers about their new products or services, for example, through different prize games [28]. Companies are now more cautious in advertising, mostly in predicting consumer responses and avoiding unpredictable errors to prevent viral responding to consumers on social networks [29]. Social networks offer advertising opportunities for small amount of money, and offer new advertising opportunities. As with communication with readers, advertising on social networks is the most important thing for imagination, innovation, and finding as many followers as possible, in this case targeted audiences. The combination of all of this will soon show good results, and there are also positive user feedback on many social networks. The goal of each ad is to reach as many people as possible, but goals can be both financially and non-financially. Advertising has the function of creating image and product or business positioning in customer awareness, market creation, changing the behavior of potential buyers and creating sales.

Marketing communications in the digital world of new media certainly have its advantages, but there are also limitations [30]. The benefits of social networking are the following. A monologue typical of television, radio and press campaigns becomes a dialogue where the campaign becomes transparent and from the consumer we get feedback that is essential for further strategic steps. Then social networks have no time limit. Every social networking advancement enables even better communication and interaction between social brands and consumers. Social networks are the only communication channel where direct communication between social brands and consumers can be achieved. Likewise, the cost of advertising on social networks is considerably lower than in traditional advertising, and you can get feedback on products or services [31].

Influencers are individuals who are extremely exposed in the digital world of social networks. These are people who have a significant influence on public decisions regarding the products they buy, the services they use, and the initiatives they are supporting. They represent how brands can connect with their target groups through a voice that potential users of products or services trust. There are influencers for all domains and industries, whether it is a fashion, sport, maternity or a general set of values that are matched to the values of a particular brand.

By developing of social media, advertisers are opening up the world of new communication capabilities, and influencer marketing is one of the most powerful tools that put brands and products in the right context and provide consumers with relevant, more natural and customized content than traditional advertising. However, influencer marketing requires a measure and strategic thinking and planning both on the side of the brand and on the side of the influencers, so that brand and influencing links are a pleasurable consumer experience and credible and effective [32]. The top criterion for assessing influencers in network communities and social networks is the level of participation, frequency of activity and importance on the market or community. The companies formally measure the effects of their initiatives through social media. Their key goals are to improve key publishing relationships, enhance reputation, boost user awareness of their online activities, and seek comments and feedback from clients. All of this is used by influencers, who can best help their businesses through their social network profiles [33].

When the influencer distributes brand messages, it helps to expose the brand message to users who do not receive the message directly from the brand, but connect the influencer with the brand message [34]. Moreover, there is consensus in the literature, and the search for opinions plays an important role in collecting information before buying, as consumers have more confidence in the opinion of influencers than traditional advertising, especially family and friends [35][36]. Furthermore, it appears that the influencers become more accessible, convincing, more intimate, and simpler than the major known people because they share personal details of their lives with their followers and interact with them almost immediately [37]. The relationship between influencers and their followers is similar and powerful as Word-of-mouth marketing. The key factor is identifying a suitable influencer. One of the most frequently used measures to identify the influencer is the number of followers [38]. However, the influencer must take into account that his postings will be permanently available on the internet and spread to an unlimited number of people [39]. Compared to traditional media with influencers, there are two points that affect the effectiveness of influencer messages. The first is the relationship between the influencers and the brand, and the second is the credibility of the influencer [40]. In addition, the human brand is every well-known person who serves as a way of using marketing communications [41]. While personal blogs and websites help establish a robust network identity, social platforms like Instagram help spread message faster, while recognizing and rewarding others [42]. All in all, as a symbolic resource for building and maintaining identity, brands give meaning and value to the consumer's personality. Thus, consumption has a symbolic meaning whether it is conscious or unconsciously. Elliot also points to life experience as practical activities and face-toface faculties in our everyday life, which are perceived as reality [43].

One of the most common activities of citizens using the Internet in 2017 was the use of social networks. More than half $(54 \%)$ of the total population aged 16-74 use the internet primarily for social networks. Between $70 \%$ and $75 \%$ of the population of Malta, Great Britain, Sweden, Belgium and Denmark use social networks. 
At the top, Iceland, which is at the top of $89 \%$, and Norway with $83 \%$ of the population using social networks. At the very bottom of this scale, there are countries using social networks between $40 \%$ and $45 \%$ of the total population, namely Slovenia, France and Italy. From the beginning until the end of 2017, the number of active users increased by $8 \%$ [44]. According to data for January 2018, out of the total number of people on Earth, as many as 3.196 billion are active users of social networks. There are about $42 \%$ of the population who are active users. Even 2,958 billion of them use social networks through their smartphones. In percent it would represent $39 \%$ of the population [45].

The most popular social network in the world is Facebook, according to figures, the total number of monthly active Facebook users is 2.17 billion. Which is even $15 \%$ more than in 2017. The share of Facebook users using mobile applications is $88 \%$. Data show that the proportion of profiles declared as women was $44 \%$, while the proportion of profiles declared as men 56\% [46]. Teens and young adults are the ones who spend most of their time on social networks, especially Facebook [47].

\section{Methodology and Sample Description}

The survey was conducted in Croatia during 2018 through a questionnaire containing 33 questions. All the data were collected in the period from 01 June 2018 (the beginning of the research) to 10 September 2018. The survey questionnaire included questions on demographic information such as age, gender and education, then questions related to usage of social networks and finally questions related to social media influencers.

The survey results were collected through Google Forms and responses were collected in one spreadsheet. The link to the survey was placed on Facebook page, the official groups within some post-graduate courses at University of Zagreb, but also distributed by other Facebook users to obtain as soon as a larger sample of respondents. Statistical analysis and visualization of data was made in MS-Excel and SPSS for Windows, version 17.0.

The designed questionnaire was based on previously conducted research in the field of online promotional methods but is partially modified according to specific issues related to influencers [33], [35], [48]. The questionnaire consisted of one-choice, multiple choice and open-ended questions, while the Likert scale questions were used to measure the satisfaction of respondents who buy through the Internet. The research was conducted on a representative sample of 325 respondents. Of the 325 respondents, $54.2 \%$ are women, and $45.8 \%$ men. The most represented age group in the sample is $18-23$ years, which includes $48.3 \%$ of the respondents. The most common group according to education is the group that had completed high school, which includes of the $36.3 \%$ respondents. There are used descriptive statistics methods, as well as inductive conclusions. There are also comparative, statistical and mathematical methods that will serve to produce graphs and tables, as well as for calculation and correct interpretation of data that are relevant for making conclusions based on research.

\section{Research results}

Of the total number of 325 respondents, $96.6 \%$ use social networks, while only $3.4 \%$ do not use social networks. Which proves that social networks have become an integral part of everyday life (Fig 1).

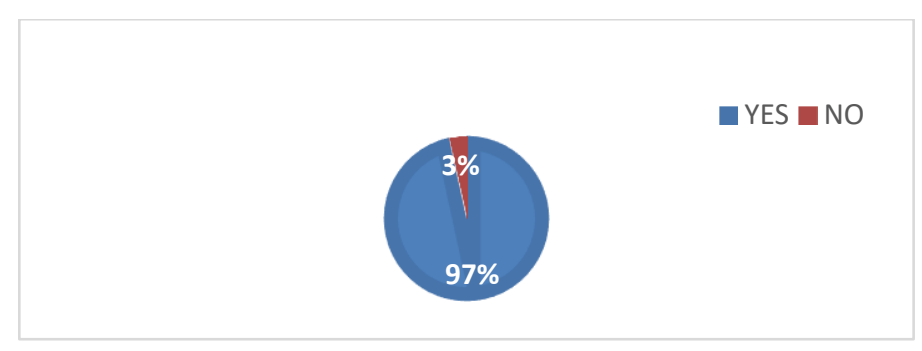

Fig. 1. Using the social networks

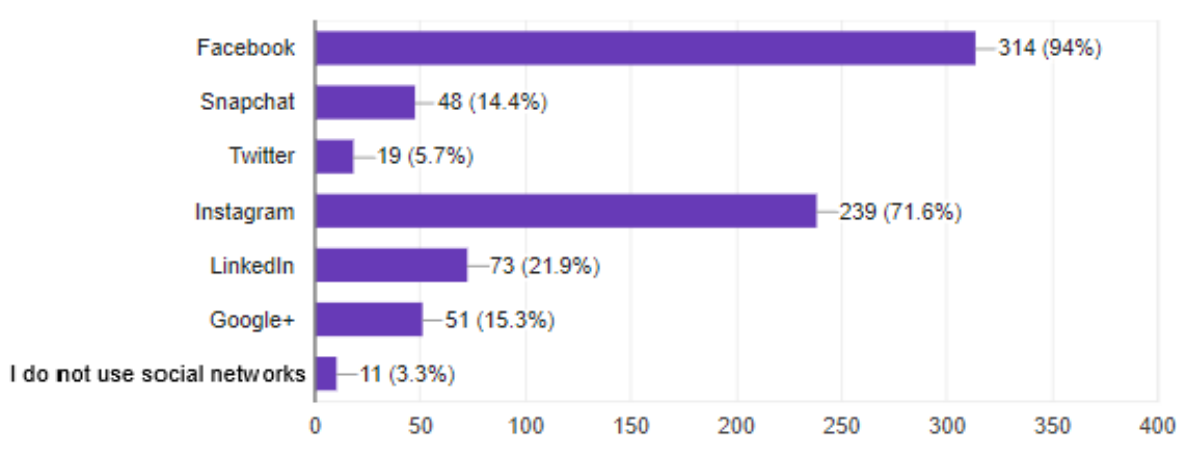

Fig. 2. Types of social networks which respondents use 
The most widely used social network is Facebook, used by $94.5 \%$ of respondents, followed by Instagram with $71.1 \%$, LinkedIn with $21.5 \%$, Google+ with $15.4 \%$, Snapchat with $14.2 \%$, and Twitter with $5.5 \%$. $3 \%$ of them do not use social networks. Facebook is the most popular social network, where respondents spend the most time (Fig 2).

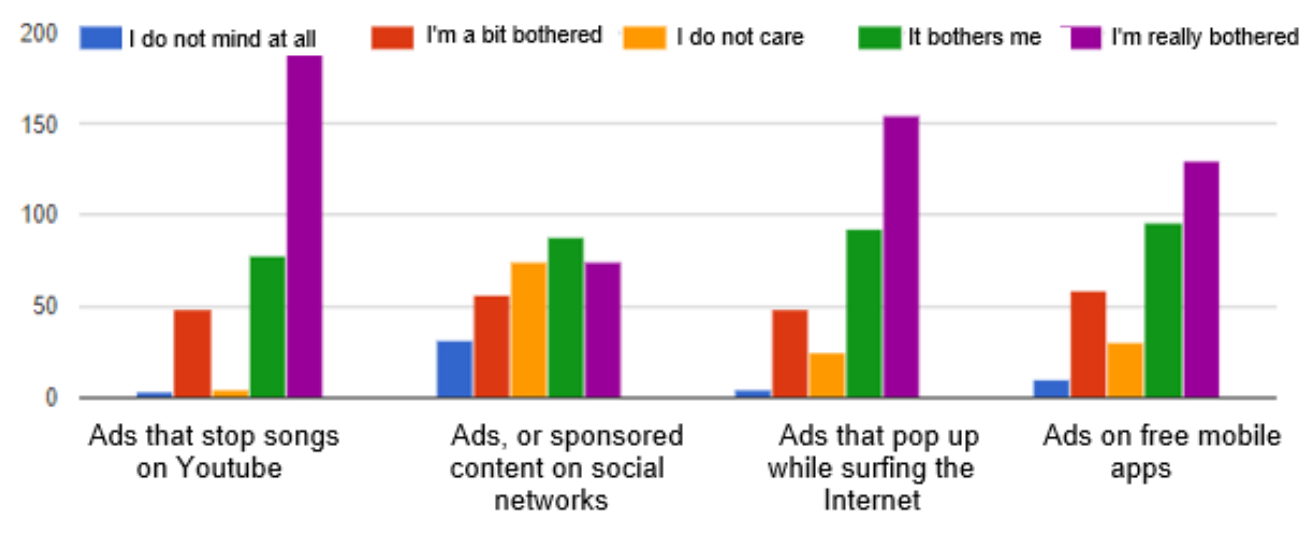

Fig. 3. Disturbance level in respondents caused by the above mentioned situations

The level of disturbance caused by ads that interrupt the songs on YouTube is as follows. The three responded that they did not mind them, 49 answered them to be a bit concerned, and 79 answered them that they do not care. That it bothers them, answered 79, with the largest number, 191 responded that they were very annoyed. The level of interference caused by ads, or sponsored content on social networks, is the following. The 32 responded that they did not mind them at all, 57 answered them to be a bit bothered, and 74 replied that they did not mind them. If they were bothered by the ads, replied 88 , with the highest number, even 75 responded that they were very annoyed. The level of disturbance caused by ads spinning during surfing the internet in the respondents is as follows. The 4 responded that they did not bother them at all, 49 responded that they were bothering them, 25 replied that they did not mind them. If they were bothered by the ads, that answered 93 of them, with the largest number, even 155 responded that they were very annoyed. The level of disturbance caused by ads on free mobile apps is as follows. The 10 responded that they did not bother them at all, 59 replied that they were bothering them, 30 replied that they did not mind them. That it bothers them, answered 97, with the highest number, even 130 responded that they were very annoyed. Which is to conclude that ads appearing as sponsored content on social networks least interfere with respondents in the time they spend on their smartphones, and that is very positive about this type of advertising (Fig 3).

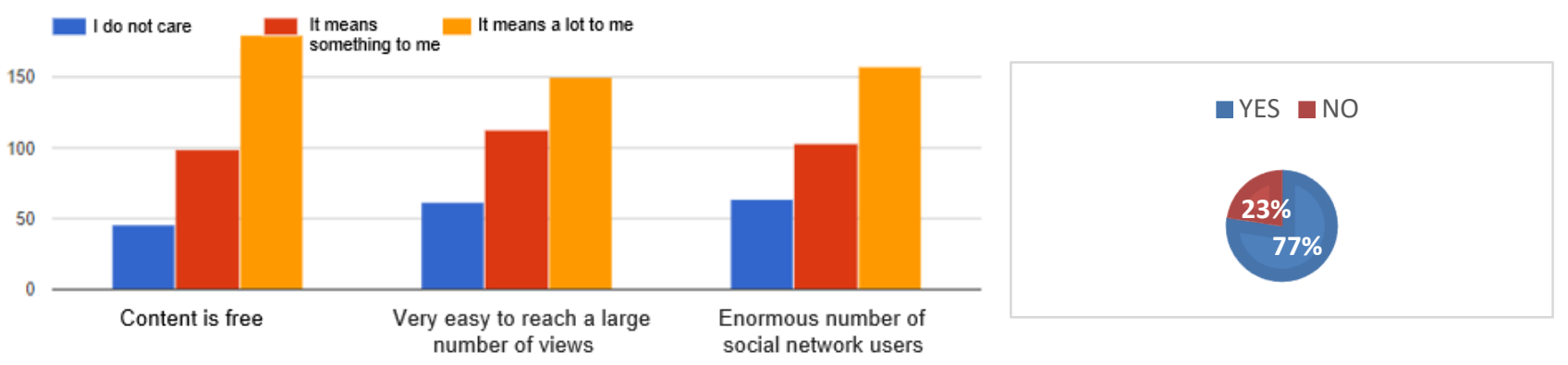

Fig. 4. Significance of certain characteristics of social network advertising among respondents

Fig. 5. Awareness of the respondents that Influencers publish their products and services in their posts

The significance of the content characteristics is free, the respondents answered are next. The 46 of them replied that it did not mean anything to them, 100 replied that it meant little to them, while 180 of them replied that it meant a lot to them. The significance of the characteristics that it is very easy to reach a large number of examinations, the respondents answered are next. The 62 of them replied that it did not mean them at all, 114 replied that it meant little to them, while the 150 responded that it meant them a lot. The importance of the characteristics that the number of social network users is exceptionally high is among the respondents. The 64 replied that it did not mean them at all, 104 replied that it meant little to them, while 158 replied that it meant them a lot. The conclusion that for each of these characteristics more than half of the respondents stated that it meant a lot, while only $15 \%$ of them in all three cases stated that they did not mean anything to them. Those who use social networks for business certainly have a lot of significance for these features (Fig 4). 
As many as 3/4 of respondents know that influencers advertise products and services in their posts. While $23.1 \%$ do not know that they are advertising their products and services in their releases. It can be concluded that those respondents who knew who the influencers know and what they do (Fig 5).

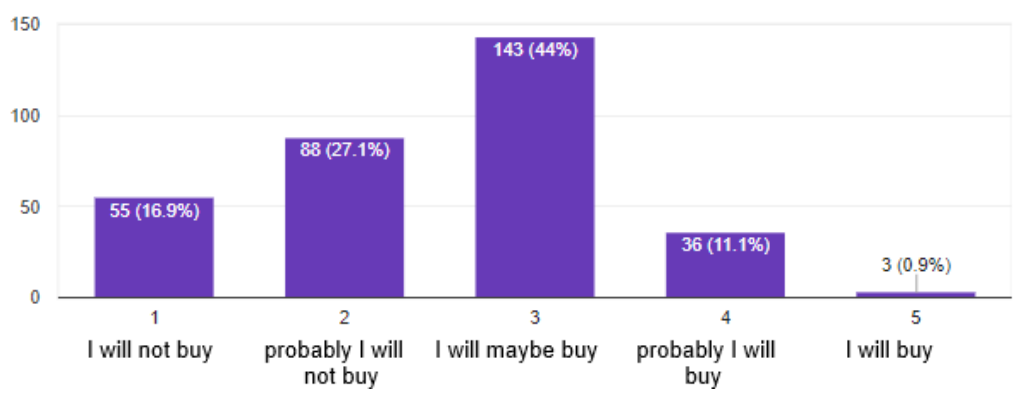

Fig. 6. Probability of buying a product or service that the respondents saw as sponsored content on a social network

The probability of buying a product or service that the respondents saw as sponsored content on a social network are the following. The largest share, $44 \%$ may buy, then $27.1 \%$ will likely buy, $16.9 \%$ will not buy, while $11.1 \%$ are likely to buy and the smallest share, $0.9 \%$ will buy that product or service. From this we can conclude that this way of marketing still does not affect enough to increase sales (Fig 6).

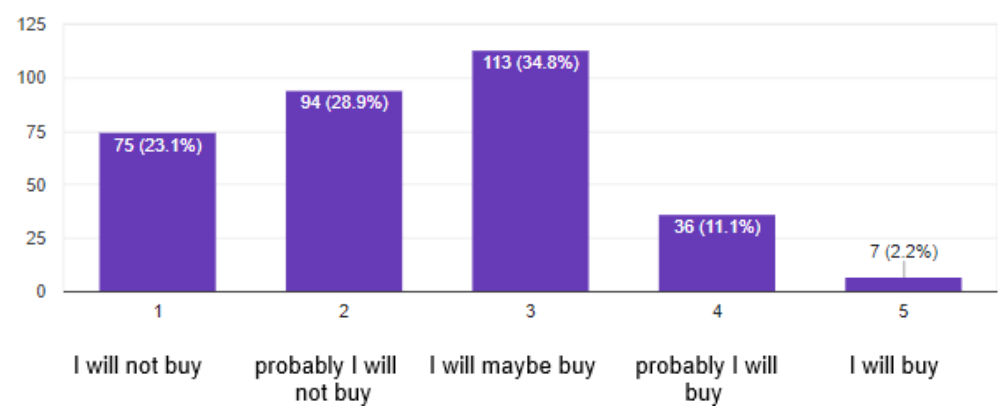

Fig. 7. Probability of buying a product or service that the respondents saw as Influencers post on a social network

The probability of purchasing a product or service that the respondents have seen as a Influencers post being monitored on the social network are the following. The largest share, of $34.8 \%$ may be purchased, then $28.9 \%$ will likely buy, $23.1 \%$ will not buy, while $11.1 \%$ are likely to buy and the smallest share, $2.2 \%$ will buy that product or service. From this we can conclude that this way of marketing still does not affect enough to increase sales. Although nearly twice as many who responded will buy a product or service they saw advertised by a person they are following on social networks (Fig 7).

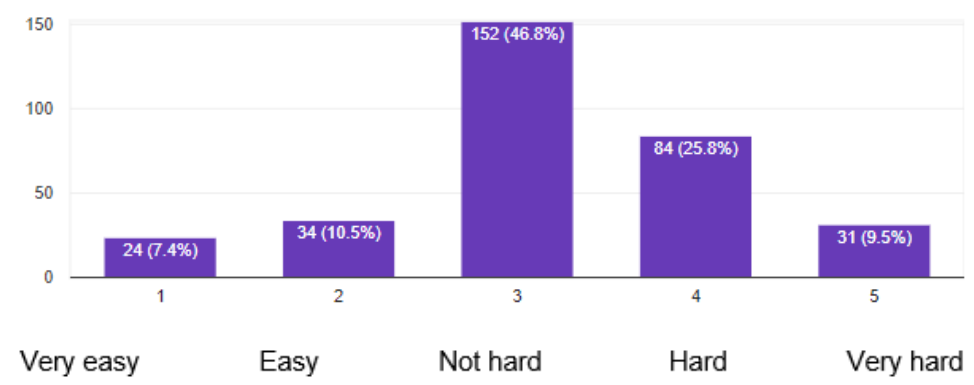

Fig. 8. The difficulty of finding an engagement Influencer in the Republic of Croatia as respondents' opinion

The largest number of respondents, almost half of them, $46.8 \%$ think it is not hard for Influencers to find engagement in the Republic of Croatia. $25.8 \%$ think that it is difficult to find an engagement, $9.5 \%$ that is very difficult, while $10.5 \%$ think it is easy, and it is very easy to consider $7.4 \%$ of respondents. From which it can be concluded that most respondents believe that influencers are difficult to find an engagement. While a smaller part thinks it is easy. And most of it thinks it is moderate (Fig 8). The largest share of respondents, almost $70 \%$ (69.5\%), will not advertise via the Influencer. The remaining $30 \%$ is ready to allocate the following amounts for post through the Influencer. Up to 70 EUR would be paid by $18.8 \%$ between 70 and 200 EUR would pay them $8.6 \%$, while $2.1 \%$ of respondents would pay between $200-400$ EUR. Only $0.9 \%$ are willing to pay more than 400 EUR per post. That was to be expected, as nearly $1 / 3$ of respondents receive up to 150 EUR per month (Fig 9). 

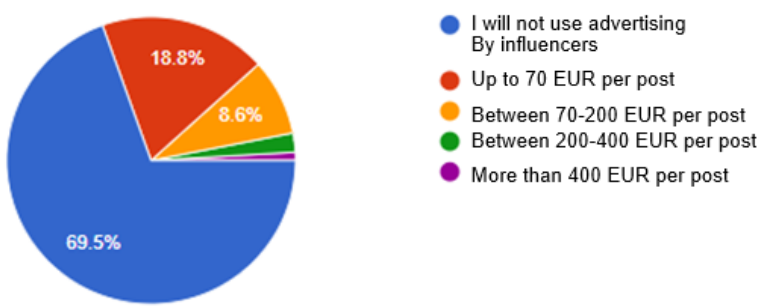

Fig. 9. The amount of money respondents are willing to pay for advertising products or services through Influencers

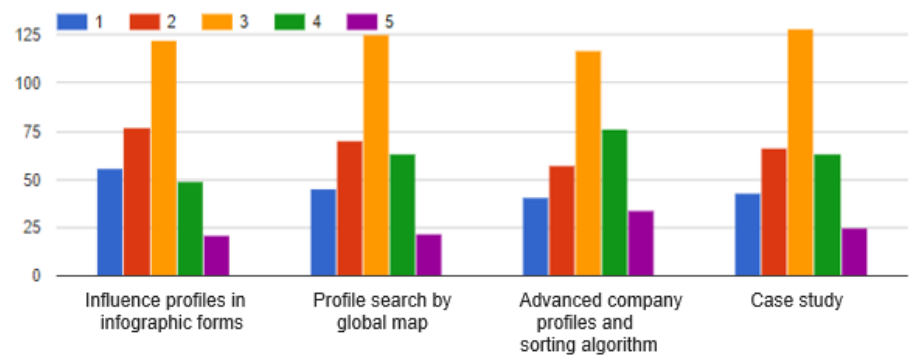

Fig. 10. Evaluation of the following innovations by the respondents

The respondents rated the innovations of influence profiles in the form of infographics. The lowest score 1 , gave 56 respondents, grade 2 gave 77 respondents, grade 3 gave 123 respondents, while grade 4 gave 49 and highest, grade 5 was given by 21 respondents. Respondents have awarded the following ratings to the search engine innovation by global mapping. The lowest score 1, gave 45 respondents, grade 2 gave 70 respondents, grade 3 gave 126 respondents, while grade 4 gave 63 and highest, grade 5 gave 22 respondents. The following ratings gave the innovations advanced company profiles and algorithm for their sorting. The lowest score 1, gave 41 respondents, grade 2 gave 57 respondents, grade 3 gave 118 respondents, while grade 4 gave 76 and highest, grade 5 gave 34 respondents. Respondents gave the following ratings to innovation in case studies and knowledge quizzes. The lowest score 1, gave 43 respondents, grade 2 gave 66 respondents, grade 3 gave 129 respondents, while grade 4 gave 63 and highest, grade 5 gave 25 examinees. It can be concluded that grade 3 is most common in all four innovations, with $30 \%$ of respondents responding. Most of the respondents are probably not best placed in these innovations and this is the reason most commonly assessed grade 3 (Fig 10).

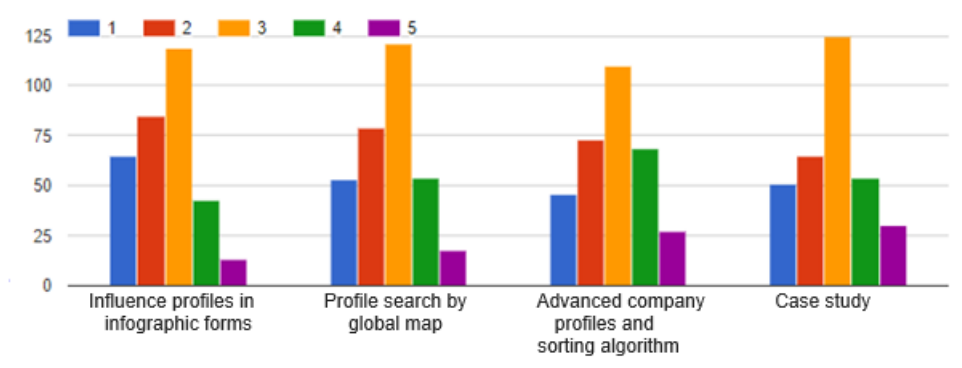

Fig. 11. Interestingness of the following innovations

The respondents gave the following ratings interestingly to the innovation of influence profiles in the form of infographics. The lowest rating of interest 1, gave 65 respondents, an interesting score of 2 was given by 85 respondents, a mean rating of 3 was given by 120 respondents, while grade 4 gave 43 and the highest rating of interest 5 , gave 13 respondents. Respondents gave the following ratings of interest to search the profile on a global map. The lowest rating of interest 1 was given by 53 respondents, an interesting score of 2 was given by 79 respondents, the average grade of interest was 3 by 122 respondents, while grade 4 gave 54 and the highest rating of interest 5 , gave 18 respondents. Respondents were given the following rating of interest by innovating advanced company profiles and algorithm for sorting them. The lowest rating of interest 1 was given by 46 respondents, an interesting score of 2 was given by 73 respondents, a mean rating of 3 was given by 111 respondents, while grade 4 gave 69 and the highest rating of 5 was given by 27 respondents. Respondents rated the following points of interest in the innovation of case studies and knowledge quizzes. The lowest rating of interest 1 was given by 51 respondents, an interesting score of 2 was given by 65 respondents, the average rating of interest was 3 by 126 respondents, while grade 4 gave 54 and the highest rating of interest 5, gave 30 respondents. It can be concluded that grade 3 is most common in all four innovations, with $30 \%$ of respondents responding. Most respondents are probably not best placed in these innovations and this is the reason most commonly rated 3 (Fig 11). 


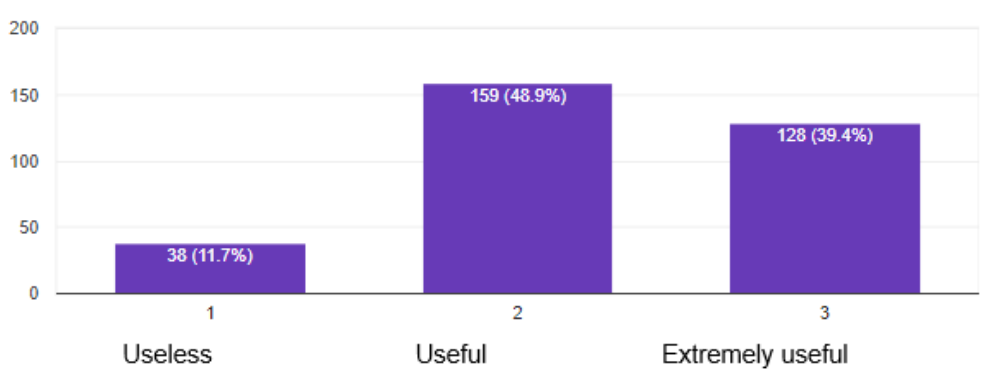

Fig. 12. Existence of the platform for connecting companies and Influencers

When asked whether the respondents think it useful to create a platform that will connect businesses and influencers, the largest share, $48.95 \%$ think it would be useful, then $39.4 \%$ think it would be extremely useful, while only $11.7 \%$ of respondents he considers this to be useless. From which it can be concluded that as many as $90 \%$ of respondents think this platform is useful or extremely useful (Fig 12). Even $93.2 \%$ of respondents did not hear about one of these platforms, and most respondents recognized Famebit and Upfluence, each responding to 10 respondents, or $3.1 \%$, then recognizing NeoReach $2.2 \%$ and Revisions only $1.2 \%$. Since there is no similar platform in the Republic of Croatia, such a response is not surprising.

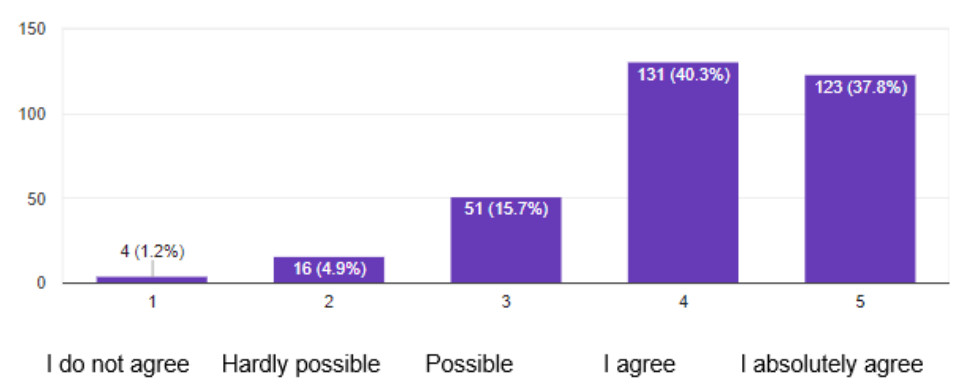

Fig. 13. The respondents' opinion on whether the most commonly used marketing in the future will be through social networks

The opinion of the respondents on whether the most commonly used marketing in the future will be that social networking is largely positive. $37.8 \%$ of them agree completely, followed by $40.3 \%, 15.7 \%$ of respondents believe it is possible. While $8.6 \%$ of respondents consider this to be difficult, and only $1.2 \%$ of respondents disagree. From which it can be concluded that almost $95 \%$ of respondents believe that the most commonly used marketing in the future will be the one through the social networks (Fig 13).

\section{Recommendations and research limitations}

Based on research, it appears that the platform itself has a high potential for market placement, as a large number of respondents are satisfied with the platform and evaluated it as passing grade. Research has shown that a lot of time per day is spent online on smartphones, even in $1 / 4$ of a day in some cases. Furthermore, social networks have become a part of everyday life and a very large number of people are using them. These have also been understood by companies that are increasingly involved in advertising through social networks, and not as much through traditional media. Similarly, research suggests that social network ads do not bother individuals. The vast majority of respondents know who the influencers are and research has shown that individuals will be more likely to buy a product, which they saw being advertised by the person they are following on the social network. Judging by the results of the research, creating a platform that connects companies and influencers is very useful and is a way to facilitate business and promotion. In each case, it will also update the essential topic of digitalization of individual services both in practice and everyday life, as well as topics for discussion and further research at the academic level.

Limitations of the research can be presented in several basic facts. The first is the number of respondents which is not sufficiently relevant for big conclusions. The number of respondents should be far greater, given that minorities can not make all decisions. Similarly, it would be necessary to set the same share of the respondents according to age, which is not the case here. The number of the student age is most represented. For these reasons, different deviations in the conduct of this survey are possible. It would certainly be necessary to carry out a larger survey with a larger representative sample to get more relevant research results. Although it is positive that the largest share of students completed the survey. Research has shown that they are the ones that spend the most time on a daily basis on a social network because it is consistent with the user habits of the population and the preference of new technologies in carrying out various transactions on a daily basis. 
It would be useful to collect data from the technical aspect of how the system is tailored to the user, how fast the user is managing through the registration, how much the user interface is simple or logical. Although the survey is carefully designed, it is not possible to avoid some drawbacks of this method, such as the lack of understanding of certain question or the inability to respond objectively. Regardless of the limitations, the results obtained are relevant and very useful indicators of certain trends.

\section{Conclusion}

Use of technology has become an integral part of human life. Research has shown that more than $95 \%$ of people have a smartphone, which makes their everyday life easier. For some people it is difficult to imagine the life without a smartphone and all the benefits that they have. The use of mobile data has been used to the same extent as having a smartphone. Most of the time spent on the internet is on social networks, which have advanced remarkably, and there is a large number of social networks that exist today, and are also used for business purposes.

Research results show that $44 \%$ of respondents spend on the Internet between 1 and 3 hours a day, while $36 \%$ spend between 4 and 6 hours on the Internet. Facebook is the most popular and most widely used social network, and it is used by as many as $94 \%$ of respondents. Interestingly, even $56 \%$ of respondents use social networks for business purposes, not just for fun. Also, of all the ads appearing on the Internet, those on social networks least annoy the respondents.

The companies used this fact in a way that they began to increasingly advertise their products and services through social networks. Reasons are numerous, and most important, as the research has shown, it is very easy to reach a large number of views. In addition, it is almost free advertising, especially by comparing this way of advertising with advertising through traditional media. In addition, through social networks, brand awareness can be gained, as well as feedback from users, and users are informed about different benefits on a daily basis.

The latest trend of advertising through social networks is the one through influencers. These are people who have a significant influence on public decisions regarding the products they buy, the services they use and the initiatives they are supporting. They represent how brands can connect with their target groups through a voice that potential users of products or services trust. The vast majority of respondents, as much as $75 \%$ have heard about them and know what they do. Research has shown that individuals will mostly buy a product if they see it being advertised by a person who they are following on the social network. In conclusion, creating a platform for connecting companies and influencers is very useful and is a way to facilitate business and promotion.

\section{References}

[1] Boyd, D. M. \& Ellison, N. B. (2007). Social Networking Sites: Definition, History, and Scholarship, Journal of Computer-Mediated Communication.13, pp. 210-220

[2] Plavljanić B. (2012). Povijest društvenih mreža, PC Chip

[3] Edosomwan S.; Prakasan S. K.; Kouame, D.; Watson, J.; Seymour T. (2011). The History of Social Media and its Impact on Business, Journal of Applied Management and Entrepreneurship, Sheffield, pp. 79-91

[4] Social Network, Mashable, Available from http://mashable.com/follow/topics/social-network/ A: 2018-09-06

[5] Scott, John P. (2000). Social Network Analysis: A Handbook (2nd edition). Thousand Oaks, CA: Sage Publications, pp. 35

[6] Powlen M.S. \& Ferrel M. B. (2013). Patent Application Publication (10) No.: US 2013/A1: Social Media Platforms Inventors

[7] Barker C. (2005). Cultural studies: Theory and Practice, pp. 448

[8] Andreas M.; Kaplan M. \& Haenlein, I. (2010). Business Horizons: Users of the world, unite! The challenges and opportunities of Social Media

[9] Tuten T.L. (2008). Advertising 2.0: Social Media Marketing in a Web 2.0 World: Social Media in a web 2.0 world, PRAEGER, pp. 3

[10] Boyd, D. M. \& Ellison, N. B. (2008). Social Network Sites: Definition, History, and Scholarship, Journal of Computer-Mediated Communication.13, pp. 220-230

[11] Harsha, G. (2008). Facebook me: Collective self-esteem, need to belong, and internet self-efficacy as predictors of the iGeneration's attitudes toward social networking sites. Journal of Interactive Advertising. 8(2), pp. 5-15

[12] Weaver A.C. \& Morrison B.B. (2008). Social Networking, IEEE Computer 41(2): pp. 98

[13] Kušić, S. (2010). Online društvene mreže i društveno umrežavanje kod učenika osnovne škole: navike Facebook generacije. Život i škola, br.56, pp. 103-125

[14] Kietzmann, J. H.; Hermkens, K.; McCarthy, I. P. \& Silvestre, B. S. (2011). Social media? Get serious! Understanding the functional building blocks of social media, pp. 241

[15] $\mathrm{Yu}, \mathrm{W} . \mathrm{W}$. (2018). English Writing via a Social Networking Platform. International Journal of Information and Communication Technology Education (IJICTE), 14(1), pp. 17-32, doi:10.4018/IJICTE.2018010102

[16] Zarrella D. (2010). The Social Media Marketing Book, O'Reilly, pp. 3

[17] Mcharty, I. (2011). Understanding the social media technology, Available from http://itdepends4.blogspot.com/2011/04/understanding-social-media-ecology.html Accessed on: 2018-09-06 
[18] Kietzmann, J. H.; Hermkens, K.; McCarthy, I. P. \& Silvestre, B. S. (2011). Social media? Get serious! Understanding the functional building blocks of social media, pp. 242

[19] Pew Research, New Media, Old Media, Available from http://pewresearch.org/pubs/1602/new-mediareviewdifferences-from-traditional-press Accessed on: 2018-06-10

[20] Scott, D. M., (2013). The New Rules of Marketing \& PR, 4th edition, John Wiley \& Sons, New York, pp. 144

[21] Ivanov, A. \& Tekic, Z. (2017). Extracting Patent-Related Information from Online Social Networks: Case of Facebook, Proceedings of the 28th DAAAM International Symposium, pp.0433-0438, B. Katalinic (Ed.), Published by DAAAM International, ISBN 978-3-902734-11-2, ISSN 1726-9679, Vienna, Austria

[22] Harris, L. \& Rae, A. (2009). Social networks: the future of marketing for small business., Journal of Business Strategy, Vol.30 Iss: 5, pp. 24-31

[23] Bercazyk, C. C. \& Duncan, D. G. (2007). Social Networking Media as a Tool for Teaching Business Administration Courses. International Journal of Humanities and Social Science Vol. 1 No. 17, pp. 267-276

[24] Tuten T.L. \& Solomon M.R. (2015). Docsity: Social Media Marketing, pp. 7

[25] Škare V. (2011). Je li potreban novi okvir za upravljanje internetskim marketingom? Tržište, Vol XXIII, br. 2, pp. $263-279$

[26] Charlesworth, A. (2009). Internet marketing: A Practical Approach, Butterworth-Heinemann, Burlington, pp. 26

[27] Karr, D., (2014). Brief History of Social Media Advertising, Marketing TechBlog. Available from https://marketingtechblog.com/brief-history-social-media-advertising/. Accessed on: 2018-06-09

[28] Shankar V. \& Malthouse E. C. (2006). Moving Interactive Marketing forward. Journal of Interactive Marketing. Vol 20, br. 1, pp. $2-4$

[29] Saravanakumar M. \& Lakshmi T.S. (2012). Life Science Journal: Social Media Marketing

[30] Ferenčić M. (2012). Praktični menadžment : stručni časopis za teoriju i praksu menadžmenta,Vol.3 No.2: Marketinška komunikacija u digitalnom svijetu, pp. 46

[31] Marketing na društvenim mrežama, Available from https://www.virtualnatvornica.com/marketing-na-drustvenimmrezama Accessed on: 2018-06-10

[32] Influencer marketing (2018). Wikipedia, Available from https://en.wikipedia.org/wiki/Influencer_marketing \#Influencer Accessed on: 2018-06-24

[33] Gillin P. (2008). New Media, New Influencers and Implications for the Public Relations Profession by Paul Gillin, Senior Fellow, Society for New Communications Research, pp. 8-9

[34] Araujo, T.; Neijens, P. \& Vliegenthart, R. (2017). Getting the word out on Twitter: the role of influentials, information brokers and strong ties in building word-of-mouth for brands. International Journal of Advertising, 36(3), pp. 496-513

[35] Roelens, I.; Baecke, P. \& Benoit, D. F. (2016). Identifying influencers in a social network: The value of real referral data. Decision Support Systems, 91, pp. 25-36

[36] Flynn, L. R.; Goldsmith, R. E. \& Eastman, J. K. (1996). Opinion Leaders and Opinion Seekers: Two New Measurement Scales. Journal of the Academy of Marketing Science, 24(2), pp. 137-147

[37] Schau, H. J., \& Gilly, M. C. (2003). We are what we post? Self-presentation in personal web space. -Journal of Consumer Research, 30(3), pp. 385-404

[38] Colliander, J. \& Dahlén, M. (2011). Following the fashionable friend: The power of social media weighing the publicity effectiveness of blogsversus online magazines. Journal of Advertising Research, 51(1), pp. 313-321

[39] De Veirman, M.; Cauberghe, V. \& Hudders, L. (2017). Marketing through instagram influencers: The impact of number of followers and product divergence on brand attitude. International Journal of Advertising, 36(5), pp. 798-828

[40] Godes, D. \& Mayzlin, D. (2004). Using Online Conversations to Study Word-of-Mouth Communication. Marketing Science, 23(4), pp. 545-560

[41] IBID, Colliander, J. \& Dahlén, M. (2011). Following the fashionable friend: The power of social media weighing the publicity effectiveness of blogsversus online magazines. Journal of Advertising Research, 51(1), 313-321.

[42] Thomson, M. (2006). Human Brands: Investigating Antecedents to Consumers' Strong Attachments to Celebrities. Journal of Marketing, 70(3), pp. 104-119

[43] Khamis, S.; Ang, L. \& Welling, R. (2017). Self-branding, 'micro-celebrity' and the rise of Social Media Influencers. Celebrity Studies, 8(2), pp. 191-208

[44] Eurostat (2017). Eurostat: Statistički podaci o digitalnom gospodarstvu i društvu - kućanstva i pojedinci, Available from http://ec.europa.eu/eurostat/statistics-explained/index.php?title=Digital_economy_and_society_ statistics_-_households_and_individuals/hr, Accessed on: 2018-06-10

[45] We are social (2018). Available from https://digitalreport.wearesocial.com/ Accessed on: 2018-06-10

[46] Statista (2018). Most famous social network sites worldwide as of April 2018, ranked by number of active users, Available from https://www.statista.com/statistics/272014/global-social-networks-ranked-by-number-of-users/ Accessed on: 2018-06-10

[47] Lenhart A.; Purcell K.; Smith A. \& Zickuhr K. (2010). Social Media and Mobile Internet Use Among Teens and Young Adults Pew Research Center: Journalism \& Media Staff, pp. 17

[48] Majstorovic, V. \& Rakic, K. (2017). Internet of Things and Social Media: Tools of a Successful Information Organization, Proceedings of the 28th DAAAM International Symposium, pp.0295-0298, B. Katalinic (Ed.), Published by DAAAM International, ISBN 978-3-902734-11-2, ISSN 1726-9679, Vienna, Austria 